\title{
¿CARGADA DE FUTURO? DEL MANIFIESTO AL ESLOGAN ${ }^{1}$
}

LOADED WITH FUTURE? FROM MOTTO TO SLOGAN

LUIS BAgUÉ QuíLEZ

Universidad de Murcia

luisbaguequilez@gmail.com

José ÁNGel Baños SALDAÑa

Universidad de Murcia

joseangel.banos@um.es

Resumen: "La poesía es un arma cargada de futuro" es el título de una de las composiciones de Cantos iberos (1955), de Gabriel Celaya, pero también uno de los lugares comunes más habituales en la poesía española de posguerra. En este artículo nos centraremos en la pervivencia del lema de Celaya en los autores de las últimas décadas del siglo xx y comienzos del siglo xxI. Dentro de este contexto cabe distinguir tres actitudes principales: la adaptación del mensaje de transformación social a la perspectiva desencantada del compromiso contemporáneo; la conversión del dictum de Celaya en un eslogan desvitalizado, no muy lejos de la retórica comercial; o la resemantización de las viejas consignas sociales en un nuevo entorno de insatisfacción cívica.

PALABRAS CLAVE: Gabriel Celaya; realismo social; resemantización; compromiso; poesía española contemporánea

ABStRACt: "La poesía es un arma cargada de futuro" is the title of a poem included in Cantos iberos (1955), by Gabriel Celaya, but also one of the most prominent common places in postwar Spanish poetry. This paper focuses on the persistence of Celaya's motto in the authors emerged in the last decades of

\footnotetext{
1 Este trabajo es resultado del Programa "Ramón y Cajal" (RYC-2014-15646), del Ministerio de Economía y Competitividad. Asimismo, se enmarca en el Proyecto de Investigación "Canon y compromiso en las antologías poéticas españolas del siglo xx" (FFI2014-55864-P), concedido por el Ministerio de Economía y Competitividad. Queremos agradecer los comentarios y sugerencias de los evaluadores anónimos, que han contribuido a mejorar este artículo.
} 
the 20th century and the beginning of the 21st century. Three main attitudes towards Celaya's message are distinguished in this period: the adaptation of the idea of social transformation to the disenchanted perspective of contemporary commitment; the conversion of Celaya's dictum into a devitalized slogan, not far from commercial rhetoric; or the resignification of the old social claims in a new context of civic dissatisfaction.

KeYwords: Gabriel Celaya; Social Realism; Resignification; Commitment; Spanish Contemporary Poetry

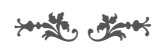

1. CARgada de RAZONeS: el PECADO original

Desde que Garcilaso se presentara ante los lectores como el perfecto cortesano, "tomando ora la espada, ora la pluma", se ha afianzado la imagen que identifica al poeta con el soldado y al arsenal retórico con la munición bélica. No obstante, el verso de la Égloga III establecía una escisión interior entre quien ejercía la milicia por obligación y cultivaba la poesía por devoción. Si avanzamos "[a] través de los siglos,/ saltando por encima de todas las catástrofes,/ por encima de títulos y fechas", como recomendaba García Montero (2014: 152-153) en "Garcilaso 1991" (Habitaciones separadas, 1994), comprobaremos que el paralelismo entre las armas y las letras no desaparece del horizonte literario, pero adquiere poco a poco dimensión colectiva y va tiñéndose de connotaciones trágicas.

En la España del siglo pasado, el estallido de la Guerra Civil exigió que los escritores volviesen a vestir el uniforme de poeta-soldado y que se aplicaran a reflejar la cruda realidad de las trincheras mediante un lenguaje "a la altura de las circunstancias". En esas coordenadas, la poesía ya no se concibe como un pasatiempo palaciego entre campañas militares más o menos remotas, sino como una acción performativa con la que los autores llaman a la movilización, apelan a los instintos populares e intentan influir en el devenir de la contienda. El valor conativo que se atribuye a la proclama instrumental o a la consigna panfletaria justifica la contigüidad metonímica y la correlación metafórica entre los útiles de escritura y las herramientas de combate, aunque esa vinculación todavía se subordine a la inmediatez sentimental y a la urgencia expresiva. Ejemplo de ello es la conferencia que impartió Miguel Hernández en el Ateneo de Alicante, el 21 de agosto de 1937, con el título de "La poesía como un arma", y que suponía una elocuente declaración de principios: "La poesía es para mí una necesidad y escribo porque no encuentro remedio para no escribir. La sentí, como sentí mi condición de hombre, y como hombre la conllevo, procurando a cada paso dignificarme [...]. En la guerra, la escribo como un arma, y en la paz será un arma también, aunque reposada" (Hernández 1992: 2227). Al margen de la impureza nerudiana y del refulgente brillo de la estética de los metales, la fuerza de esta 
analogía reaparece en la oda "A Líster, jefe en los ejércitos del Ebro", de Antonio Machado, donde el emblema de la creación (la pluma) se mide con la herramienta de la destrucción (la pistola): "Si mi pluma valiera tu pistola/ de capitán, contento moriría" (Machado 1997: 458).

La experiencia aún cercana de la Guerra Civil nos permite situar en contexto "La poesía es un arma cargada de futuro", una de las composiciones más famosas de Gabriel Celaya y uno de los espacios simbólicos más frecuentados por la poesía de posguerra. De hecho, la pieza de Cantos iberos (1955) terminaría funcionando como manifiesto instantáneo y estandarte visible de una manera de entender el impulso creativo y de evaluar la realidad. Frente al cliché, que opera en el ámbito elocutivo, el poema de Celaya podría interpretarse como la codificación textual de un ideologema (Angenot 1982: 179), definido como una proposición subyacente en un enunciado que señala la pertenencia del enunciador a un grupo particular y que focaliza una determinada representación social. ${ }^{2}$ En cuanto a Celaya, la proyección del ideologema revelaría la silueta de un autor implicado en su "misión" salvífica, dispuesto a erigirse en adalid -y eventual mártir- de la cruzada obrera. En todo caso, la equiparación de la escritura con un "arma cargada de futuro expansivo" contenía in nuce el ideario ético y estético del socialrealismo, tal como se despliega a lo largo del citado poema. A pesar de su extensión y de su amplia difusión, vale la pena transcribirlo íntegramente:

Cuando ya no se espera nada personalmente exaltante, mas se palpita y se sigue más acá de la conciencia, fieramente existiendo, ciegamente afirmando, con un pulso que golpea las tinieblas,

cuando se miran de frente los vertiginosos ojos claros de la muerte, se dicen las verdades, las bárbaras, terribles, amorosas crueldades.

Se dicen los poemas que ensanchan los pulmones de cuantos, asfixiados, piden ser, piden ritmo, piden ley para aquello que sienten excesivo.

Con la velocidad del instinto,

con el rayo de prodigio,

como mágica evidencia, lo real se nos convierte en lo idéntico a sí mismo.

Poesía para el pobre, poesía necesaria como el pan de cada día, como el aire que exigimos trece veces por minuto,

2 Ideologemas muy extendidos en la poesía social serían "el enemigo interior", "la solidaridad de clase", "la cultura", "la inmensa mayoría", "la revolución" o "el ansia de libertad" (cf. Le Bigot [en prensa]). 
para ser y en tanto somos dar un sí que glorifica.

Porque vivimos a golpes, porque apenas si nos dejan

decir que somos quien somos,

nuestros cantares no pueden ser sin pecado un adorno.

Estamos tocando el fondo.

Maldigo la poesía concebida como un lujo

cultural por los neutrales

que, lavándose las manos, se desentienden y evaden.

Maldigo la poesía de quien no toma partido hasta mancharse.

Hago mías las faltas. Siento en mí a cuantos sufren

y canto respirando.

Canto, y canto, y cantando más allá de mis penas

personales, me ensancho.

Quisiera daros vida, provocar nuevos actos,

y calculo por eso con técnica, qué puedo.

Me siento un ingeniero del verso y un obrero

que trabaja con otros a España en sus aceros.

Tal es mi poesía: poesía-herramienta

a la vez que latido de lo unánime y ciego.

Tal es, arma cargada de futuro expansivo

con que te apunto al pecho.

No es una poesía gota a gota pensada.

No es un bello producto. No es un fruto perfecto.

Es algo como el aire que todos respiramos

y es el canto que espacia cuanto dentro llevamos.

Son palabras que todos repetimos sintiendo

como nuestras, y vuelan. Son más que lo mentado.

Son lo más necesario: lo que no tiene nombre.

Son gritos en el cielo, y en la tierra, son actos.

(Celaya 1969: 630-632)

La marca de deixis temporal con la que arranca el texto remite a los imperativos de una escritura inscrita en un horizonte epocal e inserta en un momento individual concreto: "Cuando ya no se espera nada personalmente exaltante". No obstante, si las tres primeras estrofas aún se adhieren a cierta gesticulación patética propia del existencialismo tremendista -es difícil no ver en ese "fieramente existiendo" las alas del "ángel fieramente humano" que Otero había lanzado a la intemperie cinco años antes-, a partir de la tercera estrofa hallamos un auténtico depósito de tópicos ahormados según el molde de la resistencia antifranquista. En un somero inventario, cabe mencionar la confusión entre la realidad y su reflejo mimético -"lo real se nos convierte/ en lo idéntico a sí mismo"-; el afán redentorista -"Poesía para el pobre, poesía necesaria/ como el pan de cada día"-; la defensa de la impureza (compromiso) y la imprecación contra la poesía pura 
(evasión) -"nuestros cantares no pueden ser sin pecado un adorno", "Maldigo la poesía concebida como un lujo/ cultural por los neutrales"-; la heroicidad del sujeto-portavoz -"Siento en mí a cuantos sufren/ y canto respirando"-; la solidaridad afectiva con el proletariado, a partir de la identificación entre el trabajo verbal y el trabajo manual -"Me siento un ingeniero del verso y un obrero/ que trabaja con otros a España en sus aceros"-; la voluntad instrumental -"Tal es mi poesía: poesía-herramienta"-; la conmoción emotiva -"con que te apunto al pecho"-; la aspiración a la recepción mayoritaria -"Es algo como el aire que todos respiramos", "Son palabras que todos repetimos sintiendo/ como nuestras"-; el sacrificio de la belleza en aras de la autenticidad -"No es un bello producto. No es un fruto perfecto"-; o la exaltación de la utilidad revolucionaria -"Son gritos en el cielo, y en la tierra, son actos"-.

La divulgación de este programa explica al mismo tiempo el éxito fulminante del lema de Celaya y el progresivo desprestigio de los materiales sedimentados en los versos. Por un lado, la divisa "la poesía es un arma cargada de futuro" cundirá igual que la pólvora hasta consagrarse como el eslogan antonomástico de la lírica comprometida del periodo; por otro, esta fórmula se erige en una sinécdoque que equivale al discurso de toda la poesía social. En efecto, la mera alusión al mensaje de Celaya activa una constelación de motivos recurrentes, estrategias subjetivas y resortes estilísticos que asociamos de manera inmediata con el paradigma del realismo testimonial. Para bien y para mal, dicha referencia acabará siendo un estereotipo definitorio de una corriente estética: su función no es tanto apuntar hacia un lugar común como exponer una visión del mundo a través de una estructura conceptual fácilmente reconocible, reproducible y manipulable (cf. Le Bigot [en prensa]). En otras palabras, el archiconocido título del poema se eleva en el principal intertexto de la poesía social para la mayoría de críticos y lectores. ${ }^{3}$ El mismo Celaya era consciente de esta dimensión estereotípica al admitir -cierto que a regañadientes- la rentabilidad del marbete "poesía social" por una razón esencialmente práctica, esto es, porque todo el mundo intuye de qué se trata: "a mí nunca me gustó el término 'poesía social', y si a la larga he acabado aceptándolo es porque, al margen de su sentido propio, se ha convertido en algo que todo el mundo sabe a qué alude" (Celaya [1960] 1979: 745).

En los diez años que median entre Cantos iberos y la antología-cenotafio Poesía social (1965), de Leopoldo de Luis, asistimos al ascenso, el auge y la decadencia de la musa revolucionaria. A mediados de los sesenta este movimiento había depuesto su beligerancia inicial y había demostrado su capacidad de adaptación al medio gracias a la remoción de sus características inaugurales. A estas alturas, la que había sido la tendencia hegemónica en el medio siglo debía

\footnotetext{
${ }^{3}$ Es significativa al respecto la afirmación de Ángel González: “En aquellos años, finales de la década de los 50, la historia parecía confirmar el verso de Celaya" (en Lanz 2009: 21). No olvidemos que Ángel González también recurriría al lenguaje de las armas en la célebre paronomasia con la que comienza "Elegido por aclamación" (Grado elemental, 1962), en cuya primera estrofa puede verse el paralelismo entre la potencia mortífera de las pistolas y la energía destructiva de las letras: "Sí, fue un malentendido./ Gritaron: ja las urnas!/ y él entendió: ja las armas! -dijo luego./ Era pundonoroso y mató mucho./ Con pistolas, con rifles, con decretos" (González 2004: 163).
} 
protegerse de las pedradas que le llovían desde casi todos los flancos. Tanto es así que, ya en la segunda edición de Poesía social, el antólogo se apresuró a matizar algunas de las críticas que por entonces recibía, incluso desde dentro, ${ }^{4}$ la lírica social: la apremiante fecha de caducidad de sus productos, el rebajamiento de la calidad, la distancia entre eficacia y testimonio, o el espejismo de sinceridad con el que se creía tener ganado el acceso a una verdad que todavía no se había granjeado el insidioso prefijo pos- con el que la rebautizamos en nuestros días (cf. Luis [1969] 2000: 217-222). Con la irrupción de las huestes novísimas y del contingente sesentayochista se daba por definitivamente amortizada una corriente que se había devaluado al nivel de una "pesadilla estética" (Castellet [1970] 2001) o que había degenerado en un fantasma poético (cf. García 2012: 157-162), como los redivivos espectros de Marx que vagaban junto con las sombras de Hamlet por los escaparates de una posmodernidad líquida.

Aunque la pieza de Cantos iberos pasó a la historia, el leitmotiv de Celaya resurge periódicamente en la poesía española contemporánea, casi siempre emancipado del resto de la composición en la que se engastaba originalmente. En ello influye de modo decisivo su popularización a través de la canción de autor o de la canción protesta (Paco Ibáñez, Joan Manuel Serrat), que contribuyó a diluir el rótulo en la solución rítmica del estribillo. Debido a esa persistencia mnemotécnica, al descrédito histórico de la tendencia a la que se adscribe y a su paulatino vaciado significativo, hay quienes consideran que "la poesía es un arma cargada de futuro" ha dejado de ser una afirmación provocadora para reducirse a un eslogan desvitalizado, no muy lejos de los señuelos de la publicidad comercial, por más que el propio Celaya estableciera una pertinente distinción entre el poeta propagandista y el poeta publicista (cf. García 2012: 289). Volviendo a Garcilaso, se diría que el escritor social había renunciado a esgrimir la espada con gesto desafiante para resignarse a la condición de "conducido mercenario" del verso. No en vano, Celaya ya nos había avisado de que "[y]o me alquilo por horas" (1969: 297), a sabiendas de que esa disponibilidad horaria redundaría en la abdicación de la perfección formal. ${ }^{5}$ A continuación, analizaremos la repercusión que ha tenido el poema de Celaya en la poesía actual: la reubicación del mensaje dentro de la nueva poesía crítica (Riechmann, González, Wolfe); la desvalorización de dicho mensaje, equiparable a una suerte de máxima confesional (Vidal Prado); o su reciclaje en una consigna ideológica que sigue canalizando un descontento colectivo (Pérez Montalbán, Jiménez Paz, Beltrán, Xen Rabanal).

\footnotetext{
${ }^{4}$ Sin salir de la antología de Leopoldo de Luis, resulta sintomático el diagnóstico de José Hierro, que tiraba la primera piedra al señalar la irreparable pérdida de vigencia de la poesía social: "Hasta hace poco era casi un axioma para muchos la idea de que el poeta o lo era social o no era poeta de su tiempo, lo que equivale a afirmar que no era poeta. Hoy piensa la mayoría de los jóvenes que la poesía social es ya cosa del pasado. Del pasado inmediato que es, en arte, el pasado más remoto" (en Luis [1965] 2000: 344).

${ }^{5}$ En el falso soneto "A Garcilaso de la Vega" (Lo que faltaba, 1967), Celaya había opuesto, al fervor de los cantores garcilasistas, la imagen mítica de un Garcilaso guerrero y "regeneracionista". En el segundo cuarteto de la composición, donde el autor proponía cortar por lo sano con la pandemia del garcilasismo, se aprecia otra vez la secuencia poesía-arma: "Estamos con las armas en la mano,/ buscando un nuevo ritmo, fiel contraste./ Estamos, como tú nos enseñaste,/ luchando por lo nuevo y por lo sano" (Celaya 1969: 1253).
} 


\section{CARGadA de DudAs: Verso y GLOSA}

El poema de Celaya se presta a la réplica directa, a la glosa irónica y a la inversión paródica por parte de diversos autores de los ochenta y noventa, tanto si se enmarcan en el perímetro de un remozado compromiso (Jorge Riechmann, David González) como si se asimilan a la extraterritorialidad vocacional del outsider (Roger Wolfe). Para ellos, "la poesía es un arma cargada de futuro" no solo dice lo que dice, sino que convoca en fantasma todo el ideario de la poesía social. A través de un diálogo en palimpsesto, los escritores recientes refutan o matizan la premisa en la que se inspira ese programa reformista: el poder transformador atribuido a la poesía.

Ya en "Tráfico de armas", uno de los textos poéticos incluidos en las páginas del heterogéneo ensayo Poesía practicable (1990), Jorge Riechmann se alejaba del entusiasmo partidista y cuestionaba el enunciado de Celaya mediante la ruptura deliberada de las expectativas. Desde el título de la composición, Riechmann ponía en tela de juicio la metáfora fundacional que identificaba poesía y arma (cf. Le Bigot 2012: 65-66): ${ }^{6}$

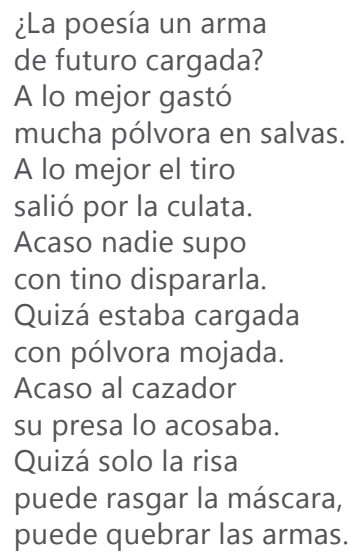

(Riechmann 1990: 166)

La definición de la poesía que había postulado Celaya (la poesía [A] es un arma cargada de futuro $[B]$ ) se reemplaza aquí por una interrogación. De esta manera, el hipertexto plantea una serie de dudas sobre la función política de la lírica mediosecular, en contraste con la seguridad en la transformación social sostenida en el hipotexto. La elisión del verbo en el primer verso y el cambio de la afirmación taxativa por una cláusula interrogativa ("¿La poesía [ø] un arma) de futuro cargada?") manifiestan la renuencia del artífice de "Tráfico de armas"

\footnotetext{
${ }^{6}$ El sintagma "tráfico de armas" favorece la ironía a través de la polisemia, pues puede vincularse con la urdimbre intertextual del poema -la acepción de tráfico como 'tránsito', 'trasiego' o 'mudanza'-, pero también designa una actividad ilícita, lo que quizá sugiera sarcásticamente que la poesía social tenía delito.
} 
a suscribir el lema antes mencionado. De hecho, en la obra de Riechmann "el deseo de transformación social se sujeta al conocimiento de la escasa incidencia que tiene la poesía en el presente, habida cuenta de sus destinatarios potenciales y de su muy restringida difusión" (Bagué Quílez 2006: 128). Ya en el nivel elocutivo se advierte una distorsión del lenguaje cercano al pueblo, mediante la incorporación de frases hechas, y una degradación de la prosodia rítmica, mediante la preferencia por los metros de arte menor -el heptasílabo, frente al predominio del alejandrino en el texto original- y el sospechoso sonsonete de las rimas asonantes en a ("quizá estaba cargada/ con pólvora mojada"). Algunas de las características de la poesía social -lenguaje accesible y cadencia musical-, camufladas bajo el velo de la parodia, se aplican a la crítica de su propia divisa. El manejo de frases hechas se puede clasificar en tres grupos, como se observa en la siguiente tabla:

\begin{tabular}{|c|c|c|}
\hline $\begin{array}{c}\text { 1. Incorporación en } \\
\text { estado natural o } \\
\text { enfatización }\end{array}$ & 2. $\begin{array}{r}\text { Alteración del estado } \\
\text { natural }\end{array}$ & $\begin{array}{c}\text { 3. } \\
\text { Inversión del uso } \\
\text { habitual }\end{array}$ \\
\hline $\begin{array}{c}\text { "Gastó/ mucha pólvora en } \\
\text { salvas" }\end{array}$ & "con tino dispararla" & $\begin{array}{c}\text { "Acaso al cazador/ su } \\
\text { presa lo acosaba" }\end{array}$ \\
\cline { 1 - 2 } "el tiro/ salió por la culata" & $\begin{array}{c}\text { "Quizá estaba cargada / } \\
\text { con pólvora mojada" }\end{array}$ & \\
\cline { 2 - 2 } & "puede rasgar la máscara" \\
\cline { 2 - 2 } & "puede quebrar las armas" \\
\hline
\end{tabular}

Tabla 1. Clasificación de las frases hechas en "Tráfico de armas"

El primer grupo apenas merece que nos detengamos en él: o bien se respetan las frases hechas tal como se suelen emplear, o bien se les añade un elemento enfático. En el segundo grupo se incluyen las reelaboraciones de frases hechas a través de la permutación. El primer caso ("acaso nadie supo/ con tino dispararla") focaliza la atención en la falta de mesura de los autores sociales. Frente a sin tino ('sin medida' y 'sin acierto'), la alteración de Riechmann ("con tino") refuerza el contenido del verso anterior para resaltar la idea de que nadie supo trabajar la poesía con prudencia ni acertó a la hora de limar sus excesos. El siguiente caso de modificación ("Quizá estaba cargada/ con pólvora mojada") responde a la intensificación del efecto paródico; es decir, la sustitución de la expresión tener la pólvora mojada por "estaba cargada/ con pólvora mojada" certifica el fracaso de la empresa realista. Más interesantes aún son "puede rasgar la máscara" y "puede quebrar las armas". Si bien formalmente sugieren una rabia contenida -rasgar es más violento que quitar la máscara, al igual que quebrar es más fuerte que rendir las armas-, semánticamente da la impresión de que los verbos podrían intercambiarse sin apenas consecuencias. Además, el orden del poema obedece a una gradación de clímax ascendente en los dos últimos versos. De este modo, el texto finaliza, en contraposición a la interrogación inicial, 
con una afirmación contundente: la risa es capaz de quebrar las armas. Quebrar las armas conlleva abandonar cierta concepción de la lírica, porque, como se aprecia en la inversión del tercer grupo, no es el cazador (el poeta) el que acosa a la presa (la poesía), sino al revés, lo que viene a rubricar la inocuidad social y literaria de este tipo de escritura.

Esta clasificación de frases hechas nos ayuda a desentrañar los principales núcleos significativos de "Tráfico de armas". Por un lado, destaca el eje isotópico de la duda como insinuación. Este aspecto se incorpora al discurso gracias a la interrogación, las constantes repeticiones de "a lo mejor" (vv. 3 y 5), "[a]caso" (vv. 7 y 11), "[q]uizá" (vv. 9 y 13), y las reiteraciones de estructuras con el verbo poder más infinitivo. Por otro lado, encontramos el eje de la derrota o del desconsuelo. Aquí se englobaría todo el vocabulario relativo a la artillería. Las frecuentes referencias a las armas concluyen con la entrega al enemigo tras haber aceptado la capitulación. Sin embargo, incluso en la adversidad, la risa es una estrategia de resistencia o un paradójico consuelo desconsolado. No en vano, "'desconsuelo' y 'resistencia' son los vocablos que mejor definen a este poeta que a menudo aconseja 'bajarse' de la autopista enloquecida del mundo actual para ponerse a observar" (Scarano 2009). Lejos de avasallar al lector con la imposición de una nueva consigna, ${ }^{7}$ el objetivo de Riechamnn es rebelarse contra la efusión sentimental de una poesía tan apasionada como acrítica. A diferencia de la retórica de los autores sociales, el propósito no consiste en convencer a los destinatarios, sino en alentar la reflexión y sembrar el germen de la disidencia:

El hecho de que un poema no pueda nada contra la muerte no es una razón para dejar de escribir elegías. Análogamente, que la poesía no sea un "arma cargada de futuro" no es una razón para dejar de escribir poesía crítica contra las relaciones sociales vigentes. (Riechmann 2002: 26)

Según Riechmann, si la lírica contemporánea ha acabado asimilándose a la inofensiva pistola de jabón que había fabricado Woody Allen en Toma el dinero y corre, quizá se deba a un desajuste entre intenciones y resultados. ${ }^{8} \mathrm{~A}$ la poesía no le corresponde acaudillar una transformación política de la sociedad, pero sí intervenir en la transformación ética de los individuos que la integran (cf. García-Teresa 2014: 124-128). ${ }^{9}$

\footnotetext{
7 Para Riechmann (2006: 131-136), uno de los pecados capitales de la lírica social fue la obsesión de los poetas por convertirse en portavoces de los que no tenían voz, lo que los conducía a falsear su propia experiencia y a adueñarse de las vivencias ajenas.

${ }^{8}$ En ese desequilibrio incide, desde una óptica burlesca y desmitificadora, "La función de la poesía" (La condición urbana, 1995), de Karmelo C. Iribarren: "La función/ de la poesía/ en nuestra sociedad/ ha sido el tema estrella/ (durante un par de días)/ en simposios, mesas orondas /y demás zarandajas,/ a cargo/ de eminencias contrastadas/ en el manejo de las lenguas. // Parece ser/ que les ha hecho/ buen tiempo,/ y que no ha habido/ heridos de importancia" (Iribarren 2016: 30).

${ }^{9}$ Son llamativas las concomitancias entre la propuesta de Riechmann y la de Blas de Otero, quien nunca compartió la decisión de "hacer de la palabra poética un instrumento de acción", y optó por concebirla más bien "como un estímulo para la conciencia liberadora de la transformación humana" (Lanz 2008: 79).
} 
Más displicente y nihilista es la actitud de Antonio Orihuela ante el redentorismo de Celaya, cuyos versos se impugnan al comienzo de uno de los textos recopilados en la antología Feroces. Radicales, marginales y heterodoxos en la última poesía española (1998), editada por Isla Correyero: "Ya hay quien, como amigo,/ empieza a decirme que esto no es poesía./ Poesía burguesa/ de esa que atesta los libros/ desde luego que no./ Tampoco es 'poesía necesaria, poesía para el pobre....'/ Los pobres están demasiado ocupados/ trabajando para que los burgueses/ puedan escribir poesía" (en Correyero 1998: 240). En este ejemplo, el prestamo de Celaya, subrayado diacríticamente mediante el entrecomillado y la cursiva, no alude al título de la composición, pues lo que se censura no es tanto la voluntad de renovación social como la ingenuidad de pretender llegar a un público que tiene que satisfacer necesidades más acuciantes que las de índole estética. Orihuela se pronunciará en términos semejantes en un poema más reciente, titulado "España" e incluido en la antología Marca(da) España (2014). El poeta retoma ahora la dialéctica de la lucha de clases para defender que los problemas urgentes de los explotados les impiden alzarse contra sus explotadores: "Yo no tengo ninguna confianza en que desde abajo/ surja algo que pueda cambiar este estado de cosas/ porque los pobres no están por hacer la revolución, / los pobres prefieren pagar la hipoteca" (en VV. AA. 2014b: 37).

Frente a la duda metódica de Riechmann y la severa indignación de Orihuela, "Glosa a Celaya" (Cinco años de cama, 1998), de Roger Wolfe, vuelve a articular una crítica directa a "La poesía es un arma cargada de futuro". Este breve poema no formula ninguna alternativa, sino que pone en juego una ironía desgarradora para burlarse de la "antigua" visión social de la poesía:

\author{
La poesía \\ es un arma \\ cargada de futuro. \\ Y el futuro \\ es del Banco \\ de Santander.
}

(Wolfe 2008: 262)

La cita palimpsestuosa actúa aquí como una réplica desautomatizadora, en la encrucijada entre diversas (inter)textualidades comprometidas en la poesía reciente (cf. Sánchez Torre 2002: 49-53). Con claras reminiscencias epigramáticas, Wolfe reproduce una glosa literal de Celaya como excusa para realizar una aportación personal: la aclaración humorística condensada en los tres últimos versos. El hipertexto recoge -en cursiva y con diferente disposición versal- las palabras del hipotexto con el fin de distanciarse de él. El humor brota no solo del desafío a las consignas demagógicas de la izquierda y de la sustitución de la lucha política por el mercantilismo, sino también de la referencia intermedial en la que se basa el poema. Por una parte, las coordenadas históricas e ideológicas en las que se enmarca el mensaje de Wolfe son muy distintas a las que alumbraron la producción de Celaya: la sociedad de consumo de nuestros días tiene poco que ver con la de la inmediata posguerra, a tal punto que el poder econó- 
mico se ha apropiado de las armas retóricas con las que peleó el socialrealismo. Por otra parte, las constantes remisiones publicitarias del Banco de Santander al futuro -véase el eslogan "Viviendo el futuro" (14 de noviembre de 1985) $)^{10}$ - le sirven al autor para generar el deseado efecto irónico. En este sentido, la ironía es un recurso liberador, útil para descargar la rabia acumulada y para justificar la cosmovisión nihilista del sujeto: "precisamente [...] porque nada merece la pena, surge la ironía: para subrayar este escepticismo" (Wolfe, en Iravedra 2010: 211).

Al margen de esta composición, Roger Wolfe procede en numerosas ocasiones a desmitificar la vinculación de la poesía con un arma de fuego. A veces la analogía se sustenta en una distancia desencantada. Así ocurre en "Poética negra" (Días perdidos en los transportes públicos, 1992), que compara la pluma con una mágnum 44, ${ }^{11}$ o en "Odio" (Arde Babilonia, 1994), que le guiña un ojo a Antonio Machado para darle la vuelta a los versos con los que este arengaba al mismísimo Líster. Frente a la movilización bélica, Wolfe se adhiere a una sublevación inmóvil -como expresaba el título del primer libro de Antonio Gamoneda- semejante a la abulia: "El odio son las cosas/ que te gustaría hacer/ con este poema/ si tu pluma/ valiera/ su pistola" (Wolfe 2008: 145). Otras veces la isotopía del armamento se subordina a la sátira literaria. En "Premio novel" (Mensajes en botellas rotas, 1996) se insinúa que quienes se acogen al famoso dictum de Celaya solo aspiran a conseguir protagonismo mediático: "La poesía aún es un arma/ cargada de futuro -dijo-. [...]/ Al día siguiente/ lo vieron todos en la página/ de cultura./ Era gordo. Barba./ Greñas, gafas./ En sus ojos/ nada especial" (Wolfe 2008: 216). Por último, a diferencia del "arma cargada de futuro expansivo/ con que te apunto al pecho", en Cinco años de cama leemos -justo en el poema posterior a "Glosa a Celaya"- que "[l]a poesía es un revólver apuntando al corazón". Roger Wolfe ha trocado el impulso expansivo que propugnaba el realismo social por un repliegue en el huis clos de la privacidad. Lo que le interesa al poeta es la fragilidad del ser humano ante "la diminuta/ inmensidad/ de su sangrante/ maltrecho/ humilde/ y finalmente esplendoroso/ corazón" (Wolfe 2008: 265). En suma, esta estética puede considerarse un claro ejemplo del callejón sin salida en el que desembocó la poesía social. Por eso, en lugar de empuñar sus versos como una herramienta transformadora, el autor prefiere emplearlos como una navaja suiza: "el arte tiene tres funciones fundamentales: proporcionar goce intelectual; hacer ver; hacer pensar" (Wolfe 2002: 30). A pesar de la falta de expectativas que destila este discurso, no cabe hablar simplemente de una insolidaridad protegida tras los muros del egotismo, sino de un individualismo conectado a la batería de la realidad (cf. Bagué Quílez 2006: 271-272; Iravedra 2006: 17).

\footnotetext{
10 El anuncio puede consultarse en la hemeroteca virtual del diario $A B C$ (< hemeroteca.abc.es/ nav/Navigate.exe/hemeroteca/madrid/abc/1985/11/14/044.html >) y en el portal de El Publicista que recoge eslóganes comerciales de varias entidades financieras (<http://www.elpublicista.es/ esloganes.php?inicio $=90 \&$ texto $=$ B\&buscar_marca $=\&$ consultar $=1>$ ).

${ }^{11}$ La proyección metaficcional de este poema se intensifica si tenemos en cuenta que el modelo de pistola al que alude el autor es el mismo que llevaba Clint Eastwood en Harry el sucio, la película de Don Siegel que Wolfe cita en el epígrafe introductorio de su ensayo Todos los monos del mundo (1995).
} 


\section{3. ¿DESCARGADA O RECARGADA? De LA MELANCOLÍA A LA INDIGNACIÓN}

La conflictiva supervivencia del lema de Celaya en el siglo xxı pasa por un proceso de desnaturalización y descarga semántica. Más cerca del eslogan comercial que de la consigna propagandística, la reiteración mecánica de "la poesía es un arma cargada de futuro" nos indica que se ha metabolizado ya como parte del patrimonio nacional, a medio camino entre la sabiduría proverbial del refrán y la gramática urgente de la pintada callejera. De este modo, no es raro que la proposición aparezca desprovista de autoría e incluso sujeta a imprecisiones mnemotécnicas: así, en los créditos finales de la película Noviembre (2003), el segundo largometraje de Achero Mañas, la frase "el arte es un arma cargada de futuro" se troquela en la pantalla sobre un decorado teatral donde resalta en primer plano la imagen de una pistola. Si la sustitución -¿deliberada?- de "la poesía" por "el arte" parece apostar por una intención más abarcadora y un destinatario más amplio, la omisión del nombre de Celaya nos autoriza a pensar que su sentencia pertenece ya al acervo popular: en otras palabras, que no es de nadie porque es de todos.

Algo similar cabría argumentar a propósito de aquellas composiciones que parafrasean a Celaya, aunque su contenido nada tenga que ver con un programa de renovación colectiva. Prueba de ello es "La poesía es un arma cargada de pasado" (Historia de un jardín muerto y de un pájaro rojo, 2015), de María José Vidal Prado. La intertextualidad se reduce exclusivamente al título, el único nexo que liga esta pieza con el discurso socialrealista. Con todo, la modificación en la orientación deíctica (futuro por pasado) nos advierte de que la dimensión proyectiva se ha reemplazado por la evocación retrospectiva:

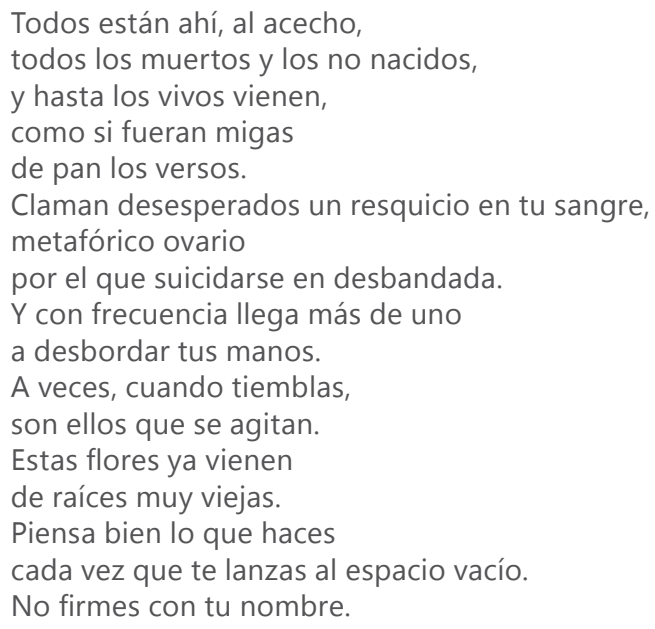

(Vidal Prado 2015: 28)

La atmósfera lírica de esta composición, rodeada de una aureola de misterio, favorece una lectura intimista y metapoética donde la desazón subjetiva 
ocupa el espacio que Celaya había reservado a las inquietudes sociales. Las principales diferencias se sintetizan en la siguiente tabla, en la que se condensan distinciones que afectan a la enunciación, al destinatario y a la propia concepción del hecho poético.

\begin{tabular}{|c|c|}
\hline Cargada de pasado & Cargada de futuro \\
\hline Poema confesional & Poema comprometido \\
\hline Sujeto: tú (desdoblamiento del yo) & Sujeto: yo/ nosotros/ tú/ vosotros \\
\hline Ellos: los recuerdos & Ellos: los neutrales \\
\hline Cuerpo individual & Organismo social \\
\hline Confidencia & Exhortación \\
\hline Escritura como exorcismo privado & Escritura como admonición coral \\
\hline $\begin{array}{c}\text { Cancelación de la identidad subje- } \\
\text { tiva (suma de recuerdos) }\end{array}$ & $\begin{array}{c}\text { Afirmación de la identidad colec- } \\
\text { tiva (suma de individuos) }\end{array}$ \\
\hline
\end{tabular}

Tabla 2. Diferencias entre "La poesía es un arma cargada de pasado" y "La poesía es un arma cargada de futuro"

Mientras que Celaya luchaba contra un enemigo tangible que había usurpado el poder político y había hecho trizas el pacto social, Vidal Prado lucha metafóricamente contra las presencias espectrales y las sombras parasitarias que invaden la memoria y que asedian la escritura. La materialidad que convocan las estrofas de "La poesía es un arma cargada de futuro" puede entenderse como el reverso del desgarro psíquico expuesto en "La poesía es un arma cargada de pasado", en cuyas tinieblas interiores se perciben los ecos trágicos de Rosalía de Castro o el universo onírico de los relatos de Poe.

Sin embargo, no todas las relecturas de Celaya en el tercer milenio exigen la demolición del andamiaje social. Al contrario, la actual crisis sistémica ha propiciado la vuelta al compromiso y la invitación al rearme realista. Sin descender a autorías concretas, cabe destacar un conjunto de iniciativas grupales que se caracterizan por su vocación testimonial. Antologías como Esto no rima. Antología de poesía indignada (2012), editada por Abel Aparicio; Marca(da) España (2014); En legítima defensa (2014); y Disidentes (2015), recopilada por Alberto García-Teresa, entroncan con la lírica de urgencia difundida desde las trincheras de la Guerra Civil. Las compilaciones mencionadas no ofrecen una revisión panorámica de la trayectoria de los autores seleccionados, sino que entregan una breve muestra que actúa como tesela documental de un mosaico en construcción. Frente a la suma de individualidades, ahora prevalece el diálogo entre voces reunidas bajo una divisa común. Asimismo, la renuncia a la confección de una jerarquía estética legitima que las autorías fuertes se diluyan en una autoría líquida y que las modulaciones personales se supediten al propósito global que 
rige estas obras. Nos hallamos, en fin, ante recopilaciones que se inspiran en un parámetro cuantitativo, en clara discordancia con el sesgo cualitativo inherente a las operaciones antológicas "convencionales". Al igual que en una movilización social, el número de colaboradores se considera un indicio probatorio de que la indignación no es privativa de un grupo de poetas cualesquiera, sino que trasluce una actitud gremial. Este planteamiento permitiría ratificar la relación de estos títulos con movimientos asamblearios como el 15-M, el acontecimiento transgeneracional en torno al que giran estos proyectos (cf. Bagué Quílez 2016).

La huella de Celaya se observa en la antología más concurrida de las anteriores: En legítima defensa, donde doscientos veintinueve autores aportan un poema -en su mayoría inédito- para dejar constancia de su insumisión ante un enemigo cada vez más deslocalizado. En el conciso prólogo del volumen, Antonio Gamoneda afirma que la mera agregación de nombres avalaría ya una actitud inconformista, semejante a la que supone la participación en una movilización o la firma de un manifiesto: "Los poetas pueden dar señal de unas convicciones que descalifican moral y socialmente al capitalismo con solo reunirse precisamente para significar su acusación, su protesta y su identificación con los despojados" (en VV.AA. 2014a: 10-11). En estas palabras se evidencia una conexión inequívoca con Celaya: por una parte, la impugnación del capitalismo transfiere al enemigo económico las mismas críticas que en los años cincuenta recaían en el enemigo político; por otra, la "identificación con los despojados" implica una actualización apenas velada de la solidaridad con los desfavorecidos que había reivindicado Celaya -recordemos la "poesía para el pobre", que suscitaría tantas adhesiones como desafecciones-. Este engarce con los temas y estilos del socialrealismo explica que en dicha antología aparezcan diversas referencias, explícitas o implícitas, a la proclama de Celaya.

El caso más llamativo es el de Isabel Pérez Montalbán, que en "Un sábado iba hacia el mercado y me abordó un indigente" reconoce en una nota al pie las paráfrasis de títulos de libros o poemas pertenecientes a Gabriel Celaya. ${ }^{12}$ La composición reconstruye un friso intertextual a partir de las obras de Celaya, pero la complicidad con uno de los padres de la poesía social no se subordina a un ejercicio de mímesis, sino que sirve de soporte a la plasmación de una experiencia personal y a la acuñación de un programa expresivo. Así se comprueba en los versos iniciales:

Yo he dicho a veces cosas tan lindas como falsas.

Con el arma cargada de verbos en presente

y verbos en futuro simple, sumo

la esperanza de vida probable, necesaria,

me oxido y me impaciento.

(en VV.AA. 2014a: 249)

12 En palabras de la autora, "en este poema-collage se citan o parafrasean lo siguientes títulos de libros o poemas de Gabriel Celaya por orden de aparición: 'La poesía es un arma cargada de futuro; Cantos íberos [sic]; Las resistencias del diamante; Las cartas boca arriba; Tranquilamente hablando; Paz y concierto; Buenos días, buenas noches; La música y la sangre; De claro en claro; Se parece al amor; El principio sin fin; Dirección prohibida; La soledad cerrada y Entreacto" (en VV.AA. 2014a: 250). 
La manida metáfora que consideraba la poesía como un arma de transformación se reactiva mediante un distanciamiento autorreflexivo. La resemantización del verso-eslogan de Celaya subraya los objetivos modestos ("futuro simple") frente a las grandes esperanzas, y la urdimbre verbal del poema frente a su dimensión social ("verbos en presente/ y verbos en futuro"). Pérez Montalbán argumenta que el escritor no trabaja con la realidad en bruto, sino con una realidad tamizada por el lenguaje. Además, aunque la autora protesta contra la situación de los inmigrantes ilegales, no aboga por soluciones universales. En lugar de adoptar un enfoque miserabilista, se centra en un asunto particular: "un emigrante sin/ permiso de trabajo, de mañana/ buscando un comedor social". No obstante, la mayor innovación se concreta en el sincretismo del plano elocutivo, donde se aprecia la fusión de registros heterogéneos: los giros coloquiales dialogan con el socialrealismo -"Ven, pongamos las cartas boca arriba,/ tranquilamente hablando, igual que gente"-; las imágenes violentas, viscosas o tentaculares, revelan una rugosidad expresionista -el hambre como "ese montón de frío y de orificio/ mordiente en el estómago del tú"-; y la torsión verbal, la creación léxica o la desconexión sintáctica ratifican la absorción de la "tradición de las vanguardias" -"Tú,/ que jerarquizas la jornada desde/ el alba mendicante a largo plazo/ a la tarde nirvana y deuda externa"-. En suma, la validez del leitmotiv de Celaya solo resulta admisible si se acepta su condición de consigna incorporada al ruido de un presente en el que convergen el vértigo informativo, los titulares periodísticos "a vuelatecla" y el zapping mental de las redes sociales.

La equiparación entre las aristas de la palabra y la función de un arma de autodefensa -cierto que más rudimentaria que la de Celaya- sigue siendo la matriz simbólica en torno a la que se articulan otros textos de En legítima defensa, como "Poema-piedra", de Antonio Jiménez Paz, y "La edad de piedra", de Fernando Beltrán ${ }^{13}$. El primero suscribe la capacidad arrojadiza de la poesía como respuesta a la devaluación cívica y a la parálisis institucional. En los versos finales, el guiño a una composición musical del cantautor cubano Pablo Milanés -"Yo pisaré las calles nuevamente" (1976)- compara la precariedad económica actual con el tema sobre el que versaba la citada canción: la situación de desamparo de la sociedad chilena tras el golpe de Estado de Pinochet. Gracias a este paralelismo intertextual, Jiménez Paz promueve la sublevación contra un sistema financiero que ha abolido las garantías democráticas y que ha sustituido la represión del fascismo político por la voracidad consumista a la que nos empujan las grandes corporaciones empresariales. ${ }^{14}$

Quién nos iba a decir que tendríamos que pisar las calles nuevamente, negarnos a besar la mentira,

\footnotetext{
${ }^{13}$ La metáfora que subyace en estas composiciones se remonta a uno de los hitos de la canción protesta en los años sesenta: "La pedra", de Raimon.

14 La censura del "fascismo de baja intensidad" (cf. Méndez Rubio 2012, 2015) al que se acoge el modelo neocapitalista puede rastrearse en otras composiciones de autores a los que ya nos hemos referido a lo largo de este artículo, como "Dictadura financiera", de Isabel Pérez Montalbán, o "Lager ex paña", de Antonio Orihuela.
} 
adoquinar los poemas y lanzarlos

contra algo, contra

alguien. ${ }^{15}$

(en VV.AA. 2014a: 163)

En cambio, Fernando Beltrán esboza un dilema similar para quedarse con las manos en la duda, suspenso entre la voluntad de reaccionar violentamente ante la violencia circundante y el sentimiento de culpa por sucumbir a la misma lógica que se pretende combatir:

Dónde. Cómo. Cuándo. Contra quién.

Aprietas cada vez más fuerte

en tu puño la piedra. Te haces daño.

Dónde arrojarla, cuándo, contra quién.

Lo sabes y no aciertas.

(en VV.AA. 2014a: 47)

A su vez, en la citada antología se incluye también "Poeta significa revólver", de Alfonso Xen Rabanal. Aunque centrado en la denuncia de la brutalidad policial al repeler una manifestación, la alargada sombra de Celaya se proyecta aquí tanto en el llamamiento conativo a los poetas ("¡Dispara!") como en la sacralización de la palabra ("el virus que nunca han podido exterminar") ${ }^{16}$. Pese a su aparente dislocación versal, esta pieza confía en la potencialidad subversiva del acto creativo con la misma fe ciega con la que lo hicieron los militantes en el socialrealismo:

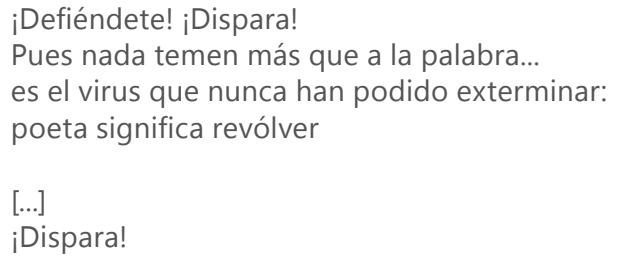

(en VV. AA. 2014a: 338)

\footnotetext{
${ }^{15}$ En su efervescencia revolucionaria, el texto de Jiménez Paz parece hacer caso omiso a la andanada irónica de Félix de Azúa en su poética para Nueve novísimos, en la que advertía: "Toda una parte de nuestra poesía actual está convencida de que un poema es un objeto arrojadizo y cuanto más arrojadizo más poético; por el contrario yo creo que lo único arrojadizo son esos poetas" (en Castellet [1970] 2001: 135).

16 Con todo, la protesta contra la "ley mordaza" protagoniza algunos textos alejados de este paradigma militante: sirva de ejemplo "Policía antidisturbios" (Poemas pequeñoburgueses, 2016), de Juan Bonilla.
} 
Estas piezas desempolvan otro de los ideologemas recurrentes en la poesía comprometida desde la Guerra Civil: el del poeta en la calle -por decirlo a la manera de Rafael Alberti-, que se vincularía con la colectivización del mensaje y con la configuración de una nueva épica social (cf. García 2012: 114-122). ${ }^{17}$ Así, si en los casos en los que se producía una descarga semántica de "la poesía es un arma..." el riesgo consistía en pronunciar el nombre de Celaya en vano, el principal peligro que deben vadear las poéticas que ahora izan este estandarte es el de tropezar con las mismas piedras que hicieron descarrilar el vagón de la lírica mediosecular.

\section{MANOS ARRIBA: RECAPITULACIÓN}

La discusión sobre la vigencia del verso-emblema de Celaya permite reflejar el regreso cíclico de ciertas preocupaciones relativas a la eficacia política en la poesía reciente. A lo largo de su evolución en los últimos treinta años, el afortunado dictum "la poesía es un arma cargada de futuro" ha atravesado tres etapas. En primer lugar, su adaptación al compromiso posmoderno requiere una compleja actualización del mensaje socialrealista; en consecuencia, los autores de los ochenta y noventa defienden la reflexión crítica frente a la transformación social (Riechmann), desconfían de salidas redentoristas (Orihuela) u oponen la ironía desengañada a la expectativa revolucionara (Wolfe). En segundo lugar, la conversión del rótulo en eslogan conlleva la desvinculación del contexto histórico y el desplazamiento desde la insurrección colectiva hasta la reprivatización lírica (Vidal Prado). Finalmente, la recuperación del lema bajo la apariencia urgente de la consigna puede desembocar en un saludable distanciamiento, mediante la síntesis entre el estilo coloquial y el legado de las vanguardias (Pérez Montalbán), o exhibir una excesiva cercanía, con el efecto colateral de incurrir en los vicios inherentes que lastraron el alcance de la musa social de posguerra (Jiménez Paz, Xen Rabanal). Quizá la lección del "realismo posmoderno" (cf. Oleza 1996) nos exima de la obligación de elegir entre los espejismos balsámicos del pasado o el galope apocalíptico de futuro, porque "la poesía no es un arma cargada de futuro sino de presente" (García Montero [1984] 1993: 204). Y el objetivo al que apunta no ha dejado de moverse ni un momento.

\section{OBRAS CITADAS}

Angenot, Marc (1982): La parole pamphlétaire. Typologie des discours modernes. París, Payot.

\footnotetext{
${ }^{17}$ Frente a la imagen patentada por Alberti, García Montero propugnaría la ubicación del poeta en "la puerta de la calle", como se titula una recopilación de sus columnas periodísticas. Este cauteloso matiz incide en el espacio de transición entre el interior doméstico y la vorágine urbana: "Se trata de jugar con una mirada propia en campos de interés colectivo, reconocerse en un detalle, sugerir como individuo privado algunas ideas de repercusión pública y penetrar con el desapego callejero de lo cotidiano en la subjetividad" (García Montero 1997: 11).
} 
Bagué Quílez, Luis (2006): Poesía en pie de paz. Modos del compromiso hacia el tercer milenio. Valencia, Pre-Textos.

— (2016): "La pesadilla que se muerde la cola: antologías poéticas del compromiso en el cambio de siglo", Anthropos, n. ${ }^{\circ} 245$, pp. 103-119.

Castellet, José María (ed.) ([1970] 2001): Nueve novísimos poetas españoles. Barcelona, Península.

Celaya, Gabriel (1969): Poesías completas. Madrid, Aguilar.

— ([1960] 1979): Poesía y verdad. Papeles para un proceso. Barcelona, Planeta.

Correyero, Isla (ed.) (1998): Feroces. Radicales, marginales y heterodoxos en la última poesía española. Barcelona, DVD.

García, Miguel Ángel (2012): La literatura y sus demonios. Leer la poesía social. Madrid, Castalia/Edhasa.

García-Teresa, Alberto (2014): Para no ceder a la hipnosis. Crítica y revelación en la poesía de Jorge Riechmann. Madrid, UNED.

García Montero, Luis ([1984] 1993): "Contra la poesía". En Confesiones poéticas. Granada, Diputación Provincial de Granada, pp. 201-204.

_ (1997): "La puerta de la calle". En La puerta de la calle. Valencia, Pre-Textos, pp. 7-14.

- (2014): Habitaciones separadas (20 años sí es algo). Ed. de Juan Carlos Abril. Madrid, Visor.

González, Ángel (2004): Palabra sobre palabra. Obra completa (1956-2001). Barcelona, Seix Barral.

Hernández, Miguel (1992): Obra completa. II. Teatro. Prosas. Correspondencia. Ed. de A. Sánchez Vidal y J. C. Rovira, con la colaboración de C. Alemany. Madrid, Espasa-Calpe.

Iravedra, Araceli (2002): “¿Hacia una poesía útil? Versiones del compromiso para el nuevo milenio", Ínsula. Revista de Letras y Ciencias Humanas, n. ${ }^{\circ} 671-672$, pp. 2-8.

_ (2006): "'Si tu pluma valiera su pistola'. El compromiso posmoderno de Roger Wolfe", Paraíso. Revista de Poesía, n. ${ }^{\circ}$ 1, pp. 9-20.

- (2010): El compromiso después del compromiso. Poesía, democracia y globalización (poéticas 1980-2005). Madrid, UNED.

Iribarren, Karmelo C. (2016): Pequeños incidentes. Antología poética. Madrid, Visor.

Lanz, Juan José (2008): Alas de cadenas (Estudios sobre Blas de Otero). Sevilla, Renacimiento.

- (2009): Las palabras gastadas. Poesía y poetas del medio siglo. Sevilla, Renacimiento.

Le Bigot, Claude (2012): "Realista y sentimental: la experiencia de la cotidianidad y su relación con la polis", Tropelías. Revista de Teoría de la Literatura y Literatura Comparada, n. ${ }^{\circ} 18$, pp. $57-73$.

—_ (en prensa): "Las ambivalencias del estereotipo en la poesía social del 50". En Luis Bagué Quílez (ed.): Cosas que el dinero puede comprar. Del eslogan al poema. Madrid/ Frankfurt, Iberoamericana/Vervuert.

Luis, Leopoldo de (ed.) ([1965] y [1969] 2001): Poesía social española contemporánea. Antología [1939-1968]. Ed. de F. Rubio y J. Urrutia. Madrid, Biblioteca Nueva.

Machado, Antonio (1997): Poesías completas. Ed. de M. Alvar. Madrid, Espasa-Calpe.

Méndez Rubio, Antonio (2012): La desaparición del exterior. Cultura, crisis y fascismo de baja intensidad. Zaragoza, Eclipsados.

— (2015): FBI. Fascismo de baja intensidad. Santander, La Vorágine. 
Oleza, Joan (1996): "Un realismo posmoderno", Ínsula. Revista de Letras y Ciencias Humanas, n. ${ }^{\circ}$ 589-590, pp. 39-42.

Riechmann, Jorge (1990): Poesía practicable. Madrid, Hiperión.

- (2002): "Encuesta a poetas, críticos y editores [Los compromisos de la poesía]", Ínsula. Revista de Letras y Ciencias Humanas, n. ${ }^{\circ} 671-672$, pp. 26-27.

- (2006): "Poesía que no cede a la hipnosis". En Resistencia de materiales. Ensayos sobre el mundo y la poesía y el mundo (1998-2004). Madrid, Montesinos, pp. 131-136.

Sánchez Torre, Leopoldo (2002): "De lo real y sus retóricas: realismo y antipoesía en las nuevas poéticas del compromiso", Ínsula. Revista de Letras y Ciencias Humanas, n. ${ }^{\circ}$ 671-672, pp. 49-53.

Scarano, Laura (2009): "Tres voces inconformistas en la aquelarre urbana (Beltrán, Riechmann y Wolfe)", Espéculo. Revista de Estudios Literarios, n. ${ }^{\circ} 42$. Disponible en <https://pendientedemigracion.ucm.es/info/especulo/numero42/tresvoc.html> [última visita: 1.4.2017].

Vidal Prado, María José (2015): Historia de un jardín muerto y de un pájaro rojo. Madrid, Vitruvio.

VV.AA. (2014a): En legítima defensa. Poetas en tiempos de crisis. Madrid, Bartleby.

VV.AA. (2014b): Marca(da) España. Retrato poético de una sociedad en crisis. Madrid, Amargord.

Wolfe, Roger (2002): "Encuesta a poetas, críticos y editores [Los compromisos de la poesía]", Ínsula. Revista de Letras y Ciencias Humanas, n. ${ }^{\circ} 671-672$, p. 30.

_ (2008): Noches de blanco papel (Poesía completa 1986-2001). Barcelona, Huacanamo. 